University of Nebraska - Lincoln

DigitalCommons@University of Nebraska - Lincoln

Drought Mitigation Center Faculty Publications Drought -- National Drought Mitigation Center

1988

\title{
Improving Projected Potential Evapotranspiration Estimates Using National Weather Service Forecasts
}

\author{
Steven J. Meyer \\ University of Nebraska - Lincoln \\ Kenneth G. Hubbard \\ University of Nebraska-Lincoln, khubbard1@unl.edu \\ Donald A. Wilhite \\ University of Nebraska - Lincoln, dwilhite2@unl.edu
}

Follow this and additional works at: https://digitalcommons.unl.edu/droughtfacpub

Part of the Climate Commons, Environmental Indicators and Impact Assessment Commons, Environmental Monitoring Commons, Hydrology Commons, Other Earth Sciences Commons, and the Water Resource Management Commons

Meyer, Steven J.; Hubbard, Kenneth G.; and Wilhite, Donald A., "Improving Projected Potential Evapotranspiration Estimates Using National Weather Service Forecasts" (1988). Drought Mitigation Center Faculty Publications. 163.

https://digitalcommons.unl.edu/droughtfacpub/163

This Article is brought to you for free and open access by the Drought -- National Drought Mitigation Center at DigitalCommons@University of Nebraska - Lincoln. It has been accepted for inclusion in Drought Mitigation Center Faculty Publications by an authorized administrator of DigitalCommons@University of Nebraska - Lincoln. 


\title{
Improving Projected Potential Evapotranspiration Estimates Using National Weather Service Forecasts*
}

\author{
STEVen J. Meyer, Kenneth G. Hubbard AND DONAld A. Wilhite \\ Center for Agricultural Meteorology and Climatology, Institute of Agriculture and Natural Resources, \\ University of Nebraska-Lincoln, Lincoln, Nebraska
}

(Manuscript received 7 November 1987, in final form 14 March 1988)

\begin{abstract}
In a recent survey conducted by the University of Nebraska's Center for Agricultural Meteorology and Climatology of Agricultural Network (AGNET) users, the results of potential evapotranspiration ( $E T_{p}$ ) projections (calculated using the Blaney-Criddle approach, which employs "normal" climatic data to project $E T_{p}$ estimates up to three days into the future) were labeled "unrealistic." To improve these projections, National Weather Service (NWS) forecast variables were used as input into the Blaney-Criddle and Penman equations. ET projections calculated according to the Penman equation, with data measured by automated weather stations as input, were assumed to represent the "best" attainable. $E T_{p}$ projections calculated using NWS forecasted values were compared with the "best" projections for the summer of 1985 . Increased accuracy in $E T_{p}$ projections due to increased accuracy in the individual forecasted input variables was evaluated.

Overall, daily $E T_{p}$ projections made with the Blaney-Criddle equation were substantially improved using the NWS forecasted temperature in place of normal temperature; over a growing season, however, accurate estimates resulted from using normal temperatures. The use of NWS-forecasted variables as input into the Penman equation offers the greatest potential for improving $E T_{p}$ projections. "Over" forecasting of all variables (relative to the estimation of $E T_{p}$ ) limited the ability of the Penman equation in this study. For greatest improvement in $E T_{p}$ projections using the Penman equation, efforts should be concentrated on improving forecasts of relative humidity and solar radiation.
\end{abstract}

\section{Introduction}

The University of Nebraska's Agricultural Network (AGNET) is one of the nation's earliest and largest time-share computer systems. Established in 1975, AGNET was designed "to provide information to those individuals, firms, and organizations that are involved in the complex production, marketing, and coordinating activities that are a part of modern agriculture" (AGNET 1983). Six of the software programs available on AGNET are "weather-based" programs, i.e., they access weather data for use directly in the program. To determine if these programs were meeting user needs, a survey regarding "weather-based" programs was undertaken in 1984 (Meyer 1986).

The validity of daily projected potential evapotranspiration $\left(E T_{p}\right)$ was questioned by respondents to the survey. The "ET" program on AGNET currently uses

* Published as Paper No. 8482, Journal Series, Nebraska Agricultural Research Division. The work reported here was conducted under Nebraska Agricultural Research Division Project 27-001 and North Central Regional Research Project 20-072.

Corresponding author address: Mr. Steven J. Meyer, Center for Agricultural Meteorology and Climatology, University of Nebraska / Lincoln, L. W. Chase Hall, Lincoln, NE 68583-0728. the more physically based Penman (1948) approach to estimate daily $E T_{p}$ for the previous fourteen days, but at the time of the survey it used the Blaney-Criddle (1950) equation to project daily $E T_{p}$ estimates up to three days into the future. According to survey respondents, the daily estimates of Penman $E T_{p}$ were acceptable. However, many suggested that the projections of Blaney-Criddle $E T_{p}$ three days into the future poorly represented actual $E T_{p}$ rates.

In 1984, the Blaney-Criddle $E T_{p}$ estimates were calculated on the basis of "normal" climatic data. It is probable that over a long period of time (such as a month or a growing season ), projections of $E T_{p}$ using the Blaney-Criddle equation and those using the Penman equation would compare favorably. Over a three-day period, however, results are likely to be poorly correlated because weather conditions are seldom "normal" over such a short time frame. A thorough discussion of both the Blaney-Criddle and the Penman approach can be found in the original papers (Blaney and Criddle 1950; Penman 1948) and in Jensen (1973).

User criticism obtained from the survey pointed out the need to improve $E T_{p}$ projections. A review of the literature revealed no previous attempts to use National Weather Service (NWS) forecasted variables in $E T_{p}$ projections. This paper reports the results of a study examining the use of NWS forecast variables as input into both the Blaney-Criddle and Penman equations 
in an effort to improve projections of $E T_{p}$ estimates in Nebraska.

\section{Materials and methods}

The only meteorological data required by the BlaneyCriddle equation for estimating $E T_{p}$ were values for temperature, while the Penman equation requires values for temperature, relative humidity, wind speed, and solar radiation. NWS zone and agricultural forecasts, issued and updated by the Omaha Weather Service Forecast Office several times daily (agricultural forecasts are prepared twice a day) for each of the 20 zones in Nebraska, were the source of data for the projection of $E T_{p}$ estimates. The four forecast zones-2, 14,15 and 16-selected for this study represent a good climatological cross section of the state (Fig. 1). The 0415 zone forecasts and the 0530 agricultural forecasts were collected from 7 June 1985 to 24 September 1985. These forecasts included predictions for "today" (0700-1900), "tonight" (1900-0700), and "tomorrow" (0700-1900 of the following day).

Variables released in the zone forecast are temperature (maximum during the 12-hour forecast period 0700-1900, and minimum during the 12-hour forecast period 1900-0700) and wind speed (a range of average speeds during each 12-hour forecast period). Variables released in the agricultural forecast are relative humidity (a range of minimum values during the 0700-1900 period, and maximum values during the 1900-0700 period) and sunshine (a range of the number of hours of sunshine to expect during the day).

An algorithm was used to convert hours of sunshine to a value of solar radiation (Doorenbos and Pruitt 1977):

$$
R_{s}=(0.25+0.50 n / N) R_{a},
$$

where: $R_{s}$ is solar radiation; $n$ the forecast average number of hours of sunshine for a 24-hour period; $N$ the maximum possible number of hours of sunshine for the 24-hour period; $R_{a}$ the amount of solar radiation received at the top of the atmosphere. The value of $R_{a}$ was taken from Doorenbos and Pruitt (1977) and is dependent on latitude and time of year only.

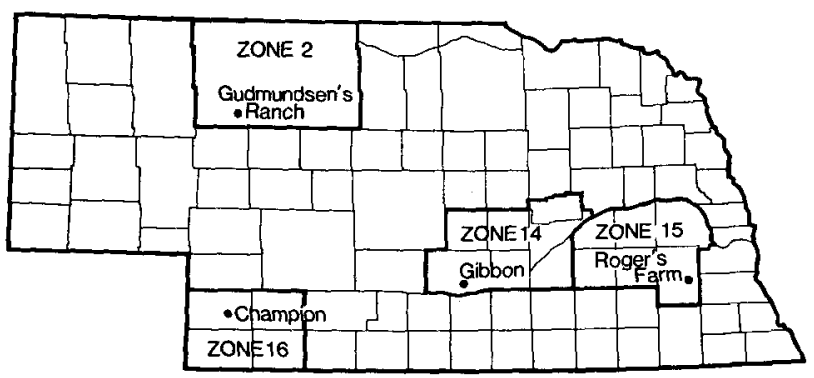

FIG. 1. Map of Nebraska showing the relationship of the four AWDN stations to the forecast zones in which they are found.
Averages for each of the forecasted variables were taken for two 24-hour periods, an average of the "today" and "tonight" forecasts $(0700-0700$ or 7A-7A in the tables) and an average of the "tonight" and "tomorrow" forecasts (1900-1900 or 7P-7P in the tables). The averaged forecasted variables were then used in the Blaney-Criddle and Penman equations to calculate projected estimates of $E T_{p}$ for the corresponding 24 hour periods.

Hourly weather data were also collected by Automated Weather Data Network (AWDN) stations (Hubbard et al. 1983). The geographical relationship of the four AWDN stations used in this study-Gudmundsen's Ranch (zone 2), Imperial (zone 16), Gibbon (zone 14), and Roger's Farm (zone 15) -and the forecast zones are shown in Fig. 1. Actual values of temperature, relative humidity, wind speed, and solar radiation measured by the automated stations were then averaged over the same time periods (0700-0700 and 1900-1900). The actual data were used in the Penman equation to calculate our best estimate of $E T_{p}$. These "best" values became the standard against which all estimates using forecast variables were compared.

The Penman method was chosen because it had been previously shown to give the best estimate of $E T_{p}$ in Nebraska. Kincaid and Heerman (1974) calibrated the Penman equation for Nebraska, and were able to use it successfully to schedule irrigations.

The effect of an improved forecast on projected $E T_{p}$ estimates was also tested, using the following procedure. Forecasted variables were replaced one at a time with actual values measured by the AWDN station. During each replacement the forecasted values were used for the remaining three variables. A new projected $E T_{p}$ estimate was made and compared to the "best" $E T_{p}$ estimate (using all measured values from the respective AWDN station). Coefficients of determination $\left(R^{2}\right.$ values) were calculated, as were the standard errors of estimates and the ratios of the mean forecasted $E T_{p}$ to the mean "best" $E T_{p}$ for the entire period. This process was repeated for each location so that one by one, each forecasted variable was replaced by its measured counterpart.

After each substitution, an increase in the coefficient of determination and/or a decrease in the standard error of the estimate provided a measure of the possible improvement in projected $E T_{p}$ estimates. The substitution that resulted in the highest coefficient of determination and/or the greatest reduction in the standard error identified the variable that, for a relative increase in NWS forecast skill, could most improve the forecasted $E T_{p}$.

The ratios of the mean forecasted $E T_{p}$ to the mean "best" $E T_{p}$ give an indication of whether $E T_{p}$ is being over- or underestimated; after each substitution, the change in a ratio can indicate the relative improvement. For example, if there is no change in the ratio after the substitution of an actual value for a forecasted value, 
TABLE 1. Coefficient of determination of $E T_{p}$, before and after the substitution of the actual (1985) data in the Blaney-Criddle and Penman equations.

\begin{tabular}{|c|c|c|c|c|c|c|c|c|}
\hline \multirow[t]{2}{*}{, } & \multicolumn{2}{|c|}{$\begin{array}{l}\text { Champion } \\
\text { (Zone 16) }\end{array}$} & \multicolumn{2}{|c|}{$\begin{array}{c}\text { Gudmundsen's } \\
\text { Ranch } \\
\text { (Zone 2) }\end{array}$} & \multicolumn{2}{|c|}{$\begin{array}{c}\text { Gibbon } \\
\text { (Zone 14) }\end{array}$} & \multicolumn{2}{|c|}{$\begin{array}{l}\text { Roger's Farm } \\
\text { (Zone 15) }\end{array}$} \\
\hline & $7 \mathrm{~A}-7 \mathrm{~A}$ & 7P-7P & $7 A-7 A$ & 7P-7P & $7 \mathrm{~A}-7 \mathrm{~A}$ & $7 \mathbf{P}-7 \mathbf{P}$ & $7 \mathrm{~A}-7 \mathrm{~A}$ & 7P-7P \\
\hline \multicolumn{9}{|l|}{ Blaney-Criddle } \\
\hline Normal temp. & 0.23 & 0.24 & 0.20 & 0.25 & 0.23 & 0.27 & 0.22 & 0.26 \\
\hline Forecast temp. & 0.40 & 0.33 & 0.35 & 0.38 & 0.37 & 0.34 & 0.38 & 0.38 \\
\hline Actual temp. & 0.57 & 0.55 & 0.55 & 0.58 & 0.56 & 0.55 & 0.58 & 0.58 \\
\hline \multicolumn{9}{|l|}{ Penman } \\
\hline All vars, forecasted & 0.66 & 0.54 & 0.61 & 0.56 & 0.58 & 0.52 & 0.59 & 0.51 \\
\hline Actual temp. & 0.73 & 0.63 & 0.70 & 0.64 & 0.67 & 0.60 & 0.68 & 0.60 \\
\hline Actual rel. hum. & 0.83 & 0.79 & 0.78 & 0.73 & 0.82 & 0.80 & 0.83 & 0.79 \\
\hline Actual wind run & 0.71 & 0.57 & 0.68 & 0.58 & 0.66 & 0.58 & 0.66 & 0.64 \\
\hline Actual solar rad. & 0.77 & 0.77 & 0.76 & 0.75 & 0.81 & 0.80 & 0.79 & 0.75 \\
\hline
\end{tabular}

chances are that the variable is not being systematically over- or underforecast. However, some variables affect the estimation of $E T_{p}$ more than others. A variable that does not affect the estimate as much as another, therefore, could be forecast with less accuracy but have comparatively less effect on the ratio.

\section{Results and discussion}

The coefficients of determination of $E T_{p}$, before and after the substitution of actual values for each of the forecasted variables, for the two 24-hour periods0700-0700 (7A-7A) and 1900-1900 (7P-7P)-are shown in Table 1. Immediately apparent are the low coefficients of determination $(0.20-0.27)$ that result from using the Blaney-Criddle equation with normal temperature as input. These coefficients improved $26 \%-74 \%$ using NWS-forecasted temperature in place of normal temperature. However, if temperature could be forecast perfectly, coefficient of determination values would improve by more than twofold over those values derived using normal temperature.

Using all forecasted variables in the Penman equation produced coefficients of determination greater than those resulting from the Blaney-Criddle equation with a perfect temperature forecast, for the 24-hour period 0700-0700. Those values for the 24-hour period 1900-1900 were nearly equal. Overall, improvements in relative humidity forecasts would most improve the ability to project Penman $E T_{p}$, as would improvements in solar radiation forecasts; while improvements in temperature and wind run forecasts would also improve Penman $E T_{p}$ projections, their effect was not as great.

The coefficients of determination consistently decrease from the 0700-0700 time period to the 19001900 time period; because a 24-hour forecast issued for the more immediate period is usually more accurate. When actual data for a particular variable are substituted (for the forecasted counterpart) it is the accuracy of the remaining three forecast variables that determines the increase in the coefficient of determination.

The differences in mean NWS forecasted data and mean actual data are shown in Table 2. Also included are the mean of the actual data and the relative error between mean forecasted and mean actual data. In general, the difference between the forecasted variables and actual values caused an overestimate of $E T_{p}$. The only exceptions were relative humidity and wind run at Gudmundsen's Ranch (zone 2) in the 1900-1900 time period. These systematic differences did not lead to a cancellation of input data errors and, when combined, will act to compound the overestimation of $E T_{p}$ projections.

In general, Gibbon (zone 14) and Roger's Farm (zone 15) were the two locations with the least accurate forecasts, and wind run was the least accurate of the forecasted variables. Individually, wind run and solar radiation at Roger's Farm, wind run and relative humidity at Gibbon, temperature at Gudmundsen's Ranch, and wind run at Imperial (zone 16) were the least accurately forecasted variables. (It is important to note that relative errors in temperature must be used with caution. In situations where temperature data are both above and below zero, relative error cannot be used.)

Forecasts of hours of sunshine may be more accurate than indicated by the solar radiation differences appearing in Table 2. Equation (1), which was used to convert hours of sunshine to solar radiation contains regional coefficients $(0.25$ and 0.50$)$ that, according to Doorenbos and Pruitt (1977), "for practical purposes . . . can be used." But for Nebraska these coefficients may be too large, which would tend to result in an overestimation of-solar radiation.

Ratios of the forecasted $E T_{p}$ to the "best" $E T_{p}$, using seasonal means, are shown in Table 3 . It is ironic that in the semiarid western portion of Nebraska (Champion and Gudmundsen's Ranch), an area similar to 
TABLE 2. Difference in the mean forecasted data and the mean actual (1985) data for each variable at each of the four locations. Also shown is the mean of the actual data and the relative error of the difference between mean forecasted and mean actual data.

\begin{tabular}{|c|c|c|c|c|c|c|c|c|}
\hline & \multicolumn{2}{|c|}{$\begin{array}{l}\text { Champion } \\
\text { (Zone 16) }\end{array}$} & \multicolumn{2}{|c|}{$\begin{array}{c}\text { Gudmundsen's } \\
\text { Ranch } \\
\text { (Zone 2) }\end{array}$} & \multicolumn{2}{|c|}{$\begin{array}{c}\text { Gibbon } \\
\text { (Zone 14) }\end{array}$} & \multicolumn{2}{|c|}{$\begin{array}{l}\text { Roger's Farm } \\
\text { (Zone 15) }\end{array}$} \\
\hline & $7 \mathrm{~A}-7 \mathrm{~A}$ & $7 P-7 P$ & $7 \mathrm{~A}-7 \mathrm{~A}$ & $7 P-7 P$ & $7 A-7 A$ & $7 P-7 P$ & $7 A-7 A$ & $7 \mathrm{P}-7 \mathrm{P}$ \\
\hline $\begin{array}{l}\text { Temp. (C) } \\
\text { Mean act. } \\
\text { Rel. error }\end{array}$ & $\begin{array}{r}0.47 \\
21.10 \\
2.2 \%\end{array}$ & $\begin{array}{r}0.58 \\
20.99 \\
2.8 \%\end{array}$ & $\begin{array}{r}1.90 \\
19.08 \\
10.0 \%\end{array}$ & $\begin{array}{r}2.04 \\
19.01 \\
10.7 \%\end{array}$ & $\begin{array}{r}1.67 \\
20.81 \\
8.0 \%\end{array}$ & $\begin{array}{r}1.83 \\
20.72 \\
8.8 \%\end{array}$ & $\begin{array}{r}1.23 \\
2,1.54 \\
5.7 \%\end{array}$ & $\begin{array}{r}1.51 \\
21.47 \\
7.0 \%\end{array}$ \\
\hline $\begin{array}{l}\text { Rel. hum. (\%) } \\
\text { Mean act. } \\
\text { Rel. error }\end{array}$ & $\begin{array}{l}-4.92 \\
64.69 \\
7.6 \%\end{array}$ & $\begin{array}{r}-4.57 \\
64.62 \\
7.1 \%\end{array}$ & $\begin{array}{r}-0.08 \\
58.57 \\
0.1 \%\end{array}$ & $\begin{array}{r}0.53 \\
58.43 \\
0.9 \%\end{array}$ & $\begin{array}{r}-12.08 \\
78.48 \\
15.4 \%\end{array}$ & $\begin{array}{r}-12.05 \\
78.37 \\
15.4 \%\end{array}$ & $\begin{array}{r}-4.19 \\
71.82 \\
5.8 \%\end{array}$ & $\begin{array}{r}-4.42 \\
71.84 \\
6.2 \%\end{array}$ \\
\hline $\begin{array}{l}\text { Wind run }\left(\mathrm{km} \mathrm{day}{ }^{-1}\right) \\
\text { Mean act. } \\
\text { Rel. error }\end{array}$ & $\begin{array}{r}59.99 \\
283.60 \\
21.2 \%\end{array}$ & $\begin{array}{r}34.78 \\
285.26 \\
12.2 \%\end{array}$ & $\begin{array}{r}18.31 \\
324.67 \\
5.6 \%\end{array}$ & $\begin{array}{r}-11.00 \\
326.01 \\
3.4 \%\end{array}$ & $\begin{array}{r}105.10 \\
254.36 \\
41.3 \%\end{array}$ & $\begin{array}{r}85.33 \\
254.01 \\
33.6 \%\end{array}$ & $\begin{array}{r}97.49 \\
255.30 \\
38.2 \%\end{array}$ & $\begin{array}{r}81.79 \\
255.43 \\
32.0 \%\end{array}$ \\
\hline $\begin{array}{l}\text { Solar rad. }\left(\mathrm{W} \mathrm{m}^{-2}\right) \\
\text { Mean act. } \\
\text { Rel. error }\end{array}$ & $\begin{array}{r}34.29 \\
524.48 \\
6.5 \%\end{array}$ & $\begin{array}{r}53.44 \\
523.65 \\
10.2 \%\end{array}$ & $\begin{array}{r}31.45 \\
524.38 \\
6.0 \%\end{array}$ & $\begin{array}{r}46.43 \\
526.91 \\
8.8 \%\end{array}$ & $\begin{array}{r}41.85 \\
488.26 \\
8.6 \%\end{array}$ & $\begin{array}{r}69.82 \\
491.50 \\
14.2 \%\end{array}$ & $\begin{array}{r}110.60 \\
417.70 \\
26.5 \%\end{array}$ & $\begin{array}{r}138.67 \\
419.88 \\
33.0 \%\end{array}$ \\
\hline
\end{tabular}

* Relative errors in temperature must be used with caution. In situations where temperature data are both above and below zero, relative error cannot be used.

that for which the Blaney-Criddle method was originally developed, $E T_{p}$ (using this method) was severely underestimated over the study period. This was true whether normal, forecast, or actual temperature was used. Also ironic was the fact that average BlaneyCriddle $E T_{p}$ estimates over the study period were very close to the average "best" $E T_{p}$ estimates in the subhumid eastern portion of the state (Gibbon and Roger's Farm), an area where the Blaney-Criddle equation should be used with caution (Ligon and Wilson 1975). At all locations, the ratio was nearly the same, whether using normal or forecast temperature, and decreased when actual temperature was used. This implies that, for a seasonal estimate of $E T_{p}$, normal temperature can be used in the Blaney-Criddle equation without any loss of accuracy.

Because nearly all variables were overforecast (underforecast in the case of relative humidity), $E T_{p}$ projections using the Penman equation were too high compared to "best" estimates. The ratios show that $E T_{p}$ projections were overestimated an average of $10 \%$ at Gudmundsen's Ranch (Zone 2) and as much as $57 \%$ at Gibbon (Zone 14). It is quite apparent that in the eastern zones (14 and 15 ), which had the least accurate forecasts, the largest overestimation of $E T_{p}$ occurred $(51 \%-57 \%)$.

TABLE 3. Ratios of the forecasted $E T_{p}$ to "best" $E T_{p}$, using seasonal means, before and after the substitution of the actual (1985) data in the Blaney-Criddle and Penman equations. Immediately below each zone is the mean daily $E T_{p}(\mathrm{~mm})$ for that time frame during the study period.

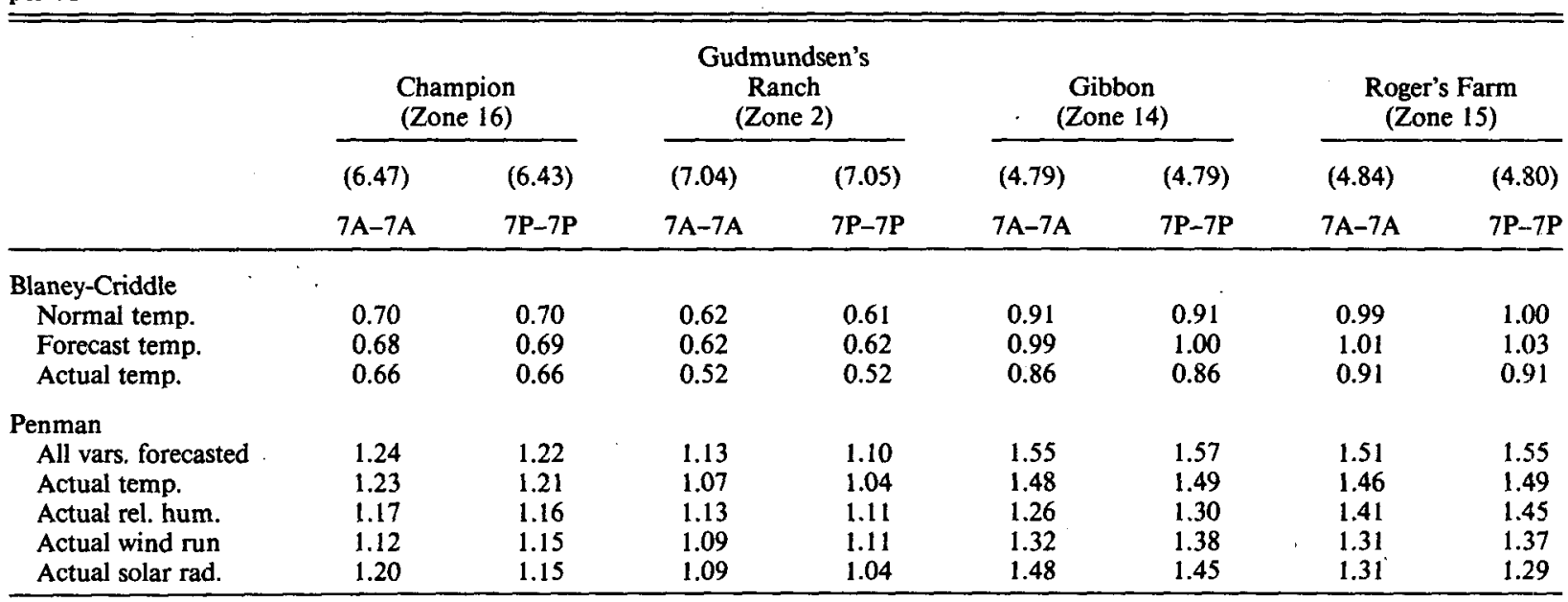


TABLE 4. Standard error of the estimates of $E T_{p}(\mathrm{~mm})$, before and after the substitution of the actual (1985) data in the Blaney-Criddle and Penman equations. Immediately below each zone is the mean daily $E T_{p}(\mathrm{~mm})$ for that time frame during the study period.

\begin{tabular}{|c|c|c|c|c|c|c|c|c|}
\hline & \multicolumn{2}{|c|}{$\begin{array}{l}\text { Champion } \\
\text { (Zone 16) }\end{array}$} & \multicolumn{2}{|c|}{$\begin{array}{c}\text { Gudmundsen's } \\
\text { Ranch } \\
\text { (Zone 2) }\end{array}$} & \multicolumn{2}{|c|}{$\begin{array}{l}\text { Gibbon } \\
\text { (Zone 14) }\end{array}$} & \multicolumn{2}{|c|}{$\begin{array}{c}\text { Roger's Farm } \\
\text { (Zone 15) }\end{array}$} \\
\hline & $(6.47)$ & $(6.43)$ & $(7.04)$ & (7.05) & $(4.79)$ & (4.79) & $(4.84)$ & $(4.80)$ \\
\hline & $7 \mathrm{~A}-7 \mathrm{~A}$ & $7 P-7 P$ & $7 A-7 A$ & $7 P-7 P$ & $7 \mathrm{~A}-7 \mathrm{~A}$ & 7P-7P & $7 \mathrm{~A}-7 \mathrm{~A}$ & 7P-7P \\
\hline \multicolumn{9}{|l|}{ Blaney-Criddle } \\
\hline $\begin{array}{l}\text { Normal temp. } \\
\text { Forecast temp. } \\
\text { Actual temp. }\end{array}$ & $\begin{array}{l}3.15 \\
1.48 \\
1.35\end{array}$ & $\begin{array}{l}2.93 \\
1.52 \\
1.33\end{array}$ & $\begin{array}{l}2.96 \\
1.61 \\
1.39\end{array}$ & $\begin{array}{l}2.62 \\
1.48 \\
1.29\end{array}$ & $\begin{array}{l}2.88 \\
1.55 \\
1.33\end{array}$ & $\begin{array}{l}2.65 \\
1.54 \\
1.35\end{array}$ & $\begin{array}{l}2.86 \\
1.54 \\
1.31\end{array}$ & $\begin{array}{l}2.56 \\
1.49 \\
1.32\end{array}$ \\
\hline \multicolumn{9}{|l|}{ Penman } \\
\hline $\begin{array}{l}\text { All vars. forecasted } \\
\text { Actual temp. } \\
\text { Actual rel. hum. } \\
\text { Actual wind run } \\
\text { Actual solar rad. }\end{array}$ & $\begin{array}{l}1.75 \\
1.63 \\
1.53 \\
1.45 \\
1.48\end{array}$ & $\begin{array}{l}1.61 \\
1.53 \\
1.42 \\
1.40 \\
1.27\end{array}$ & $\begin{array}{l}1.72 \\
1.55 \\
1.46 \\
1.48 \\
1.46\end{array}$ & $\begin{array}{l}1.51 \\
1.42 \\
1.37 \\
1.48 \\
1.28\end{array}$ & $\begin{array}{l}1.88 \\
1.65 \\
1.37 \\
1.49 \\
1.37\end{array}$ & $\begin{array}{l}1.67 \\
1.56 \\
1.21 \\
1.37 \\
1.27\end{array}$ & $\begin{array}{l}1.80 \\
1.61 \\
1.45 \\
1.51 \\
1.24\end{array}$ & $\begin{array}{l}1.63 \\
1.54 \\
1.42 \\
1.29 \\
1.17\end{array}$ \\
\hline
\end{tabular}

The ratios in Table 3, using the Penman equation, generally agree well with the relative error in the forecast data found in Table 2. For example, at Imperial (zone 16) the ratio was virtually unchanged with the substitution of actual temperature for forecasted temperature because the mean forecasted temperature was very near that of the mean actual temperature. The small relative error of relative humidity and solar radiation decreased the ratio slightly. Wind run, however, having the most relative error in the forecasted data, had a tendency to decrease the ratio toward unity more than the other variables in the 0700-0700 time frame.

These ratios indicate which variables affect the estimation of $E T_{p}$ the most, when differences between mean forecasted and mean actual data become relatively large. For example, at Gibbon (zone 14) the ratio shows the greatest decrease when actual relative humidity is substituted for forecasted relative humidity, even though the relative error is only $15.4 \%$ (compared to relative errors of $41.3 \%$ and $33.6 \%$ for wind run during the 0700-0700 and 1900-1900 time frames, respectively). This is also seen at Roger's Farm (zone 15 ), where solar radiation has the same effect on the ratio, with less relative error, than does wind run, although this example is not as dramatic.

The standard error of estimate is shown in Table 4 for each of the four locations. Most obvious is the very high standard error associated with the Blaney-Criddle equation using normal temperature as input, as well as the drastic reduction in the standard error (up to 53\% at Gudmundsen's Ranch) when forecast temperature is used in place of normal temperature. The standard error can be reduced even further with a better temperature forecast.

Using all forecasted variables in the Penman equation resulted in standard errors of greater magnitude than when using forecasted temperature in the BlaneyCriddle equation. We assume that this is due to sys- tematic "bias" in the forecast data (all variables are systematically overforecasted relative to the estimation of $E T_{p}$ ), which, as previously stated, acts to compound the error. These errors are large enough that in most cases a perfect forecast of one variable does not reduce the standard error to a magnitude lower than that of the standard error using a perfect temperature forecast in the Blaney-Criddle equation. However, using the Penman equation, substantial reductions in the standard error are possible with better forecasts of both solar radiation and relative humidity.

Why the relative error was smaller for the later forecast period is not fully understood. The errors in the variables may interact differently in the two time frames. As seen in Table 2, the error in the temperature forecast increased very slightly at all locations going from the $0700-0700$ to the $1900-1900$ time frame, the error in relative humidity remained nearly constant, the error in wind run decreased at all locations, and the error in solar radiation increased at all locations. The collective interactions of these changes may be the key. However, the answer may be academic since the magnitude of the differences is so small.

\section{Summary and conclusions}

From a survey of AGNET "weather-based" program users it was determined that projections of $E T_{p}$ up to three days into the future using the Blaney-Criddle approach (with "normal" temperature as input) were unrealistic. A method of improving these projections, using NWS forecasted variables as input into both the Blaney-Criddle and Penman equations, was studied.

AWDN stations, located in the chosen forecast zones, collected actual data. From these data, $E T_{p}$ was estimated using the Penman equation and became the standard or "best" $E T_{p}$ against which all estimates using forecast data were compared. 
From this study it was clear that NWS forecasted values were systematically higher (except relative humidity, which was systematically lower) than their measured counterparts, a systematic difference that led to an overestimation of projected $E T_{p}$. By substituting actual data for forecasted data, one variable at a time, improvements in forecasts were simulated. Following each substitution, forecasted $E T_{p}$ was compared to "best" $E T_{p}$ calculated from measured variables.

By substituting NWS-forecast temperature in place of normal temperature, projections of Blaney-Criddle $E T_{p}$ estimates can be substantially improved on a daily basis. Evidence of this is seen in the increases in the coefficient of determination and decreases in the standard error of the estimate. Some additional improvement could be made if NWS temperature forecasts were improved. The ratios of forecasted $E T_{p}$ to "best" $E T_{p}$ for the season lead us to conclude that the use of daily normal temperature as input into the Blaney-Criddle equation provides as good an estimate of seasonal $E T_{p}$ as Blaney-Criddle estimates made with forecast or actual temperatures.

By examining the coefficient of determination and the standard error of the estimate, it was also determined that there is considerable potential in the use of NWS-forecasted variables as input into the Penman equation to project $E T_{p}$ estimates. However, systematic overforecasting of all variables (relative to the estimation of $E T_{p}$ ) by the NWS leads to a systematic overestimation of projected $E T_{p}$. Relative humidity and solar radiation proved to have the greatest effect on $E T_{p}$ estimates. For the greatest improvement in projected $E T_{p}$ estimates, we conclude that efforts should be concentrated on improving the forecasts of these two variables. However, removal of systematic differences between the forecasted and measured wind run would also improve $E T_{p}$ projections.
Acknowledgments. The authors wish to thank Professor Norman L. Klocke and Mr. Phil Clark for their critical review of this paper. We are also grateful for the assistance and cooperation of the staffs at the Omaha National Weather Service Office and at KRVN radio in Nebraska. Our sincere thanks also go to Mrs. Sharon Kelly for the preparation of the manuscript. The work reported was conducted under Nebraska Agricultural Research Division Project 27-001 and North Central Regional Research Project 20-072. This material is based on the work supported by the National Climate Program Office (Grant No. 87-123-032-01).

\section{REFERENCES}

AGNET, 1983: Annual Report. University of Nebraska-Lincoln, 8 pp.

Blaney, H. F., and W. D. Criddle, 1950: Determining water requirements in irrigated areas from climatological and irrigation data. U.S. Dept. Agric., Soil Cons. Serv., SCS-TP-96, 48 pp.

Doorenbos, J., and W. O. Pruitt, 1977: Guidelines for predicting crop water requirements. FAO Irrig. and Drainage Paper 24 (rev.), $156 \mathrm{pp}$.

Hubbard, K. G., N. J. Rosenberg and D. C. Nielsen, 1983: Automated weather data network for agriculture. J. Water Resour. Planning and Management, 109(3), 213-222.

Jensen, M. E., Ed., 1973: Consumptive use of water and irrigation water requirements. American Society of Civil Engineers, 215 pp:

Kincaid, D. C., and D. F. Heerman, 1974: Scheduling irrigation using a programmable calculator. Agricultural Research Service, North Central Region \#12, 55 pp.

Ligon, J. T., and T. V. Wilson, 1975: Water balance computations based on evapotranspiration estimates. ASAE paper 75-2027. 21 pp.

Meyer, S. J., 1986: Improving Nebraska's near-real time weatherbased products through user interaction. CAMaC Progress Rep. $86-4,239$ pp.

Penman, H. L., 1948: Natural evaporation from open water, bare soil, and grass. Proc. Roy. Soc. London, A193, 120-145. 